\title{
Single Cross Hybrid of QPM Maize Seed Production as Influenced by Row Ratio and Spacing in North Western Himalayan Region
}

\author{
Vikas Sharma*, Anil Bhushan, Deepak Kumar, Sunil Mishra and Rajesh Kumar \\ Regional Agricultural Research Station, Rajouri of SKUAST-Jammu, (J\&K), India \\ *Corresponding author
}

\section{A B S T R A C T}

\section{Keywords}

Hybrid Maize, QPM and Row ratio

Article Info

Accepted:

15 July 2020

Available Online:

10 August 2020
A field experiment was conducted during the kharif season of 2016 and 2017 at Regional Agricultural Research Station, Rajouri of SKUAST-Jammu, to study the effect of row ratio of male and female parents and Spacing on single cross QPM maize (Zea mays L.) hybrid seed production. The experiment was laid out in FRBD design with three replications, constituting 8 treatment combinations involving two factors viz., spacing in main plots $\left(\mathrm{S}_{1}\right.$ - $60 \mathrm{~cm} \times 20 \mathrm{~cm}$ and $S_{2}-75 \mathrm{~cm} \times 20 \mathrm{~cm}$ ) and four row ratios of male and female parents $\left(\mathrm{R}_{1}-1: 2, \mathrm{R}_{2}-1: 3, \mathrm{R}_{3}-1: 4\right.$ and $\left.\mathrm{R}_{4}-1: 5\right)$ in sub- plots of Vivek QPM- 9 i.e., VQL -2 and VQL - 1. Row spacings $S_{2}(75 \mathrm{~cm} \times 20 \mathrm{~cm})$ gave significantly higher hybrid seed yield over the row $S_{1}(60 \mathrm{~cm} \times 20 \mathrm{~cm})$ spacing. The same results were obtained in case of number of cobs per plant, cob length, no of grains per cob and 100 grain weight. The higher B: C ratio (1:2.25) was observed in case of row spacing $S_{2}$ over $S_{1}$ (1:1.91). As regards to effect of row ratio on seed yield the maximum hybrid seed yield (16.40 q / ha) was obtained in the row ratio of male and female parents $R_{2}(1: 3)$, which was statistically superior to other treatments followed by row ratio $\mathrm{R}_{3}(1: 4)$. The similar trend was observed with respect to yield attributing characters number of cobs per plant, cob length, no of grains per cob and 100 grain weight. There was no significant interaction between row ratio and spacing. As regards the profitability of single cross hybrid seed production of QPM as influenced by the different treatments the highest net income of $₹ 94553$ and B: C ratio of 2.78 was obtained in 1:3 ratios of male and female parents over the other row ratios i.e., 1:2, 1:4 and 1:5ratios. However the row spacing of $(75 \mathrm{~cm} \times 20 \mathrm{~cm})$ was more remunerative than the closer spacing of $(60 \mathrm{~cm} \times 20 \mathrm{~cm})$. The highest hybrid seed yield of single cross hybrid maize was recorded $16.40 \mathrm{q} /$ ha with row spacing of $75 \mathrm{~cm} \times 20 \mathrm{~cm}$. and 1:3 ratios of male and female parents over the other ratios i.e., 1:2, 1:4 and 1:5 ratio.

\section{Introduction}

Maize (Zea mays L.) is an important cereal crop of the world which provides nutrition as well as phytochemial compounds for human beings and animals. It is a third leading crop of the world after rice and wheat and considered as a staple food in many part of the world. The world wide Maize trade for the year 2020 is forecasted to reach around 167 million tons, almost unchanged from the previous year (Anonymous 2020). The 
increase in world Maize production in the last two decades is associated with intensification in use of hybrid seed of Maize. Maize being a C4 plant has the higher potential for synthesis of carbohydrate. In India Maize contributes 9.7 per cent of the total food grain production of the country. In the northern Himalayan Union Territory of Jammu and Kashmir, it is the second important food crop after rice and a major food item for the tribal and hilly population. The productivity level of Jammu and Kashmir $1837 \mathrm{~kg} /$ ha is far below than the national average $2509 \mathrm{~kg} \mathrm{/} \mathrm{ha}$ (Anonymous 2018). In order to achieve the goals of food and nutrition security, endeavor must be taken to bring more and more production area under quality protein maize hybrids especially in the north western Himalayan region. The adaptation of QPM can contribute immensely to alleviation of malnutrition and improving livelihood security in our region. Therefore, production of quality hybrid of maize is of paramount importance for enhancing protein content in daily meals of individuals and thus ensuring them the balanced diet for their proper growth and development. One of the prime limiting factors in increase productivity of this crop is unavailability of quality seed of improved hybrids. Quality Protein Maize (QPM), developed in the late 1960's, contains 55 per cent more tryptophan, 30 per cent more lysine, 38 per cent less leucine and higher niacin availability due to a higher tryptophan and lower leucine content, higher calcium and carbohydrate, and carotene utilization than that of normal maize (Prasanna et al., 2001). It has good kernel, taste and appearance like normal maize. Normal maize endosperm, consist less than 9 per cent protein which is either deficient in two essential amino acids or has very low level of lysine and tryptophan. Better protein quality in QPM is expected to help in reducing protein malnutrition among the rural masses. It also provides nutritionally rich feed and fodders to poultry feed, livestock, swine and fishes. It may be helpful in poverty alleviation programme through less dependency of farmers on private seed companies for seed, easy viability of QPM cultivars hybrid seed in the local market, high economic return to the farmers and entrepreneurship development among the farming community.

Crossing between two desirable inbreds as a male and female parents and deriving $F_{1}$ or hybrid from the cross is called a single cross hybrid. Hybrids are reckoned as best quality seeds for high yields and wider adaptability. Farmers mainly depend on private seed companies for their hybrid seed requirement which is an expansive input in the cultivation process. Very few cultivars of QPM are available with private seed companies. Single cross hybrids are vigorous, uniform in height and maturity, possess high resistance to insect-pests and diseases and have wider adaptability which makes them more productive. Production of the seed of single cross hybrid is easier in comparison to other hybrids since it involves two inbred lines (parents), requires less isolation and time. It has being reported that male: female row ratio mainly depends on the pollen shedding ability, duration of male parent, season, area under seed production and male: female synchrony (Jithendra et al., 2013). Hybrid seed production of maize crop influenced largely by several agronomic and management factors, among which planting ratio, staggered sowing and row spacing are important.

One of the basic requirements in production of hybrid seeds is used to optimum plant population and planting ratios of pollen parent to seed parent to get higher seed set and yield. The pattern of planting ratio contribute substantially for the uniform supply of pollen to all the seed parent rows in achieving higher seed set and yield. An adequate availability of 
inter and intra row spacing is necessary for enhancing metabolic activities of the plant which intern influence the plant growth. This would be achieved by efficient utilization of biological resources such as solar energy, water and nutrients. Plant geometry is one of the major management aspects; which is limiting the seed production of maize. Optimum spacing would help in efficient utilization of solar energy with less competition for growth factors The poor seed yield noticed in many maize hybrids is mainly attributed to the nicking problem existed between male and female parents. Even in well synchronized plots, the seed yield was found to be far less from expectation which may be due to various reasons like wind direction, velocity and availability of insufficient viable pollens to female parent.

Therefore, one of the basic requirements in hybrid seed production is to find out optimum planting ratio and plant population to provide sufficient quantity of viable pollens to the seed parent during flowering period for ensuring increased pollination and fertilization to obtain higher hybrid seed set and yield. The present investigation, therefore, was undertaken to standardize the agro-technology for single cross hybrid seed production of Quality Protein Maize to evaluate the impact of row ratio of male and female parents and spacing on single cross maize (Zea mays L.) hybrid seed production for optimum yield under north western Himalayan region.

\section{Materials and Methods}

The field experiment was conducted at research farm of Regional Agricultural Research Station, Rajouri of SKUASTJammu situated between $33.38^{0}$ north latitude and $74.31^{\circ}$ east longitude with altitude of $915 \mathrm{~m}$ amsl. Experiment was carried out during kharif 2016 and 2017 to evaluate the suitable row ratio of male and female parents, effect of spacing for optimum yield and economics of single cross maize hybrid seed production of Quality Protein Maize under Rajouri conditions. The experiment was laid out in factorial randomized block design (FRBD) with three replications in $6 \mathrm{~m} \times 6 \mathrm{~m}$ plots taking two spacing in main plots $\left(\mathrm{S}_{1}-60\right.$ $\mathrm{cm} \times 20 \mathrm{~cm}$ and $S_{2}-75 \mathrm{~cm} \times 20 \mathrm{~cm}$ ) and four row ratios of male and female parents $\left(\mathrm{R}_{1}-\right.$ $1: 2, \mathrm{R}_{2}-1: 3, \mathrm{R}_{3}-1: 4$ and $\left.\mathrm{R}_{4}-1: 5\right)$ in subplots of Vivek QPM- 9 i.e., VQL -2 and VQL - 1. The soil of the experimental field was clay loam in texture with $190.4 \mathrm{~kg} / \mathrm{ha} \mathrm{N}, 8.4$ $\mathrm{kg} / \mathrm{ha} \mathrm{P}_{2} \mathrm{O}_{5}$ and $123.2 \mathrm{~kg} / \mathrm{ha}$ available $\mathrm{K}_{2} \mathrm{O}$ and having a $\mathrm{pH}$ of 7.71. The crop was grown with the uniform fertilizer doses i.e., Nitrogen $-90 \mathrm{~kg}, \mathrm{P}_{2} \mathrm{O}_{5}-60 \mathrm{~kg}, \mathrm{~K}_{2} \mathrm{O}-30 \mathrm{~kg}$ and $\mathrm{ZnSO}_{4}$ - $25 \mathrm{~kg}$ per hectare as per the recommendation of the university. Insect pest and disease management was done uniformly in all plots. The crop was sown on $22^{\text {nd }}$ of May, 2016 and $28^{\text {th }}$ of May in the year 2017, about 20 days prior to the general sowing time in this area to provide time isolation for maintaining genetic purity. The tassel of the female lines was removed as they came out from the plant to fertilize all the seed on female plants from the male parent. Observations were recorded on growth parameters, yield attributing characters and seed yield. Pooled data for two years was subjected to the analysis of variance for test of significance using standard procedure given by Gomez and Gomez (1984).

\section{Results and Discussion}

The data presented in Table 1 showed that the days to tasseling and silking tend to increase with decrease in plant spacing however row ratio is not significant and interaction between spacing and row ratio is also not significant. The maximum days to tasseling (57.5) and silking (59.6) were recorded under the lower row spacing $(60 \mathrm{~cm} \times 20 \mathrm{~cm})$, while the lowest 
days to tasseling (55.7) and silking (57.8) respectively were noted under the wider $\operatorname{spacing}(75 \mathrm{~cm} \times 20 \mathrm{~cm})$. The maturity of the crop was also affected by the spacing narrow the spacing earlier the maturity (97.1). Similar findings have been made by Gaire et al (2020).The row spacings does not affect the barrenness per cent significantly however male: female row ratios have significant effect on barrenness more the parent ratio more the barrenness. Significant variation was observed with respect to lodging percentage by the row spacing closer the spacing more the lodging per cent but row ratio had no significant effect on lodging. Both spacing and row ratio of parents had significant effect on shelling per cent of Maize crop.

Table.1 Effect of spacing and row ratio on days to tasseling, silking, 75 per cent dry husk, barrenness, lodging and shelling percent of QPM

\begin{tabular}{|c|c|c|c|c|c|c|}
\hline Treatments & $\begin{array}{l}\text { Days to } \\
\text { tasseling }\end{array}$ & $\begin{array}{l}\text { Days to } \\
\text { silking }\end{array}$ & $\begin{array}{c}\text { Days to } 75 \% \\
\text { dry husk }\end{array}$ & $\begin{array}{c}\text { Barrenness } \\
(\%)\end{array}$ & $\begin{array}{c}\text { Lodging } \\
(\%)\end{array}$ & $\begin{array}{l}\text { Shelling } \\
(\%)\end{array}$ \\
\hline \multicolumn{7}{|l|}{ Spacing $(\mathbf{c m})$} \\
\hline$S_{1}$ & 57.5 & 59.6 & 97.1 & 3.3 & 2.20 & 78.40 \\
\hline $\mathbf{S}_{2}$ & 55.7 & 57.8 & 98.6 & 3.4 & 1.90 & 81.15 \\
\hline $\mathrm{CD}(\mathrm{P}=\mathbf{0 . 0 5})$ & $1 . .28$ & 1.33 & 0.88 & N.S & 0.18 & 1.80 \\
\hline \multicolumn{7}{|c|}{ Row Ratio (Male: Female) } \\
\hline $\mathbf{R}_{1}$ & 58.1 & 61.2 & 97.5 & 3.1 & 2.5 & 80.90 \\
\hline $\mathbf{R}_{2}$ & 57.3 & 60.4 & 98.2 & 3.2 & 2.6 & 80.10 \\
\hline $\mathbf{R}_{\mathbf{3}}$ & 57.5 & 59.6 & 96.8 & 3.5 & 2.8 & 77.40 \\
\hline $\mathbf{R}_{4}$ & 56.4 & 58.4 & 98.4 & 3.6 & 2.6 & 76.23 \\
\hline $\mathrm{CD}(\mathrm{P}=\mathbf{0 . 0 5})$ & N.S & N.S & N.S & 0.23 & N.S & 1.12 \\
\hline
\end{tabular}

Table.2 Effect of treatments on yield attributing characters, hybrid seed yield (F1) and Economies of QPM

\begin{tabular}{|c|c|c|c|c|c|c|}
\hline Treatments & $\begin{array}{l}\text { No. of } \\
\text { Cobs / } \\
\text { Plant }\end{array}$ & $\begin{array}{l}\text { No. of } \\
\text { Grains } \\
\text { Cob }^{-1}\end{array}$ & $\begin{array}{c}100 \\
\text { Grain } \\
\text { Wt. (g) }\end{array}$ & $\begin{array}{c}\text { Hybrid seed } \\
\text { yield } \\
\left(\text { q ha }^{-1}\right)\end{array}$ & $\begin{array}{c}\text { Net } \\
\text { Return } \\
\left(\text { Rs. ha }{ }^{-1}\right)\end{array}$ & B:C ratio \\
\hline \multicolumn{7}{|l|}{ Spacing (cm) } \\
\hline $\mathbf{S}_{1}$ & 1.33 & 369.31 & 189.29 & 13.23 & 67490 & 1.91 \\
\hline $\mathbf{S}_{\mathbf{2}}$ & 1.39 & 387.20 & 196.35 & 14.74 & 76231 & 2.25 \\
\hline $\mathrm{CD}(\mathrm{P}=\mathbf{0 . 0 5})$ & 0.12 & 14.63 & 0.06 & 1.10 & --- & --- \\
\hline \multicolumn{7}{|c|}{ Row Ratio (Male: Female) } \\
\hline $\mathbf{R}_{1}$ & 1.38 & 413.18 & 193.63 & 13.48 & 69756 & 1.97 \\
\hline $\mathbf{R}_{\mathbf{2}}$ & 1.37 & 411.88 & 196.46 & 16.40 & 94553 & 2.78 \\
\hline $\mathbf{R}_{3}$ & 1.28 & 372.77 & 182.10 & 13.76 & 74810 & 2.18 \\
\hline $\mathbf{R}_{4}$ & 1.16 & 335.85 & 180.58 & 12.20 & 58687 & 1.69 \\
\hline $\mathrm{CD}(\mathrm{P}=\mathbf{0 . 0 5})$ & 0.10 & 29.61 & 0.10 & 1.41 & --- & --- \\
\hline
\end{tabular}


Perusal of pooled data presented in the Table 2 revealed significant differences in two row spacings with $S_{2}(75 \mathrm{~cm} \quad x \quad 20 \mathrm{~cm})$ gave significantly higher hybrid seed yield over the row $S_{1}(60 \mathrm{~cm} \times 20 \mathrm{~cm})$ spacing. The same results were obtained in case of number of cobs per plant, cob length, no of grains per cob and 100 grain weight. The higher B: C ratio $(1: 2.25)$ was observed in case of row spacing $S_{2}$ over $S_{1}(1: 1.91)$.The results are in consonance with the results reported by Enujeke (2013).

As far as the effect of row ratio on seed yield is concerned, the results revealed maximum hybrid seed yield (16.40 q / ha) in the row ratio of male and female parents $R_{2}$ (1:3), which was statistically superior to other treatments followed by row ratio $R_{3}$ (1:4). The similar trend was observed with respect to yield attributing characters number of cobs per plant, cob length, no of grains per cob and 100 grain weight these results confirmed the finding of Widdicombe and Thelen (2002). Benefit: Cost ratio analysis was also carried out for different treatments. The results revealed treatment $R_{2}$ showed highest $B$ : C ratio $(1: 2.78)$.

There was no any interaction effect in row ratio and row spacing as per the pooled data for both the years. The study on the relative economics and profitability of single cross hybrid seed production of QPM as influenced by the different treatments the maximum net monetary returns (NMRs) of Rs. 94553 and benefit: cost ratio of 2.78 was fetched by $1: 3$ ratios of male and female parents over the other row ratios i.e., 1:2, 1:4 and 1:5ratios. However the wider row spacing of $(75 \mathrm{~cm} \times 20$ $\mathrm{cm})$ gave the net returns of Rs. 76231 and $\mathrm{B}: \mathrm{C}$ ratio (2.25) which was more remunerative than the closer spacing of $(60 \mathrm{~cm}$ $\mathrm{x} 20 \mathrm{~cm}$ ) having net return and $\mathrm{B}: \mathrm{C}$ ratios of Rs. 67490 and 1.91 respectively. The highest hybrid seed yield of single cross hybrid maize was recorded $16.40 \mathrm{q} /$ ha with row spacing of $75 \mathrm{~cm} \times 20 \mathrm{~cm}$. and 1:3 ratios of male and female parents over the other ratios i.e., 1:2, 1:4 and 1:5 ratios.

\section{References}

Anonymous.2020.Crops Prospects and Food Situation-Quarterly Global Report No.1 of FAO: Rome, Italy

Anonymous.2018. Statistical year book India, Ministry of statistics and programme implementation, Government of India.

Ramhari Gaire, Chudamani Pant, Nischal Sapkota, Rajan Dhamaniya and Tej Narayan Bhusal. 2020.Effect of Spacing and Nitrogen Level on Growth and Yield of Maize (Zea mays L.) in Mid hill of Nepal. Malaysian Journal of Halal research Journal. 3(2):50-55

Jithendra, D.B., G.V.Basvaraju, G.Sarika \& N.Amrutha. 2013. Effect of Fertilizer Levels and Planting Geometry on Growth and Seed Yield of Single Cross Maize Hybrid NAH-2049 (Nithyashree). Global Journal of Biology, Agriculture and Health Science. 2(3): 216-220

Enujeke E. C.2013. Effects of variety and spacings on growth character of hybrid maize. Asian Journal of Agriculture and Rural Development. 3:296-310

Gomez, K.A. and Gomez, A.A. 1984. Statistical Procedures for Agricultural Research. $2^{\text {nd }}$ ed. John Wiley and Sons, New York.

Prasanna, B.M., Vasal, S.K., Kassahun, B. and Singh, N.N., 2001.Quality Protein Maize. Current Science 81:1308-1319

Widdicombe WD and Thelen KD. 2002. Row Width and Plant Density Effects on Corn Grain Production in the Northern Corn Belt. Agronomy Journal 94: 10201023. 


\section{How to cite this article:}

Vikas Sharma, Anil Bhushan, Deepak Kumar, Sunil Mishra and Rajesh Kumar. 2020. Single Cross Hybrid of QPM Maize Seed Production as Influenced by Row Ratio and Spacing in North Western Himalayan Region. Int.J.Curr.Microbiol.App.Sci. 9(08): 1491-1496.

doi: https://doi.org/10.20546/ijcmas.2020.908.172 